\title{
The Three "Musketairs" - Lasker Prize 2016 goes to the protagonists of hypoxia research
}

\author{
Roland H Wenger' \\ Dörthe M Katschinski ${ }^{2}$ \\ 'Institute of Physiology, University of \\ Zurich, Zurich, Switzerland; ${ }^{2}$ Institute \\ of Cardiovascular Physiology, \\ Georg-August University Göttingen, \\ Göttingen, Germany
}

This article was published in the following Dove Press journal:

Hypoxia

25 November 2016

Number of times this article has been viewed

Who does not know them? One bearded like a pirate, one knighted by the Queen, and one of noble spirit. United in the fight for truth and honor! No, this is not about Alexandre Dumas' characters Porthos, Athos, and Aramis, well-known from the famous novel The Three Musketeers. ${ }^{1}$ This is about the most recent awardees of the Albert Lasker Basic Medical Research Award, the three protagonists of hypoxia research Gregg Semenza, Sir Peter Ratcliffe, and Bill Kaelin. The recent bestowal of the Lasker Prize is just another hallmark in a long list of recognitions of the major achievements by these three outstanding colleagues. What major victories in the battle against the unknowns in hypoxia research did our three heroes achieve?

Undoubtedly, Gregg Semenza initiated the hypoxia tale by cloning, together with his combatant Guang L Wang, the hypoxia-inducible factor. Following his initial description in 1992 of a unique hypoxia-inducible band in electrophoretic mobility shift assay $(\text { EMSA })^{2}$, designated hypoxia-inducible factor (HIF), many tried to unravel the nature of this protein binding to the erythropoietin 3'-hypoxia response element. But it was not until 1995 that Wang and Semenza succeeded in identifying HIF as a heterodimer consisting of a known protein (HIF-1 $\beta$ or ARNT) and a novel hypoxia-inducible protein $(\mathrm{HIF}-1 \alpha){ }^{3}{ }^{3}$ Their cloning attack followed a classical but tedious strategy: purifying the activity from hundreds of liters of cell culture and using EMSA to trace the suspect. All the many other sophisticated strategies devised by competing groups basically failed. Nevertheless, the finding that HIF regulates not only erythropoietin but hundreds of other target genes ${ }^{4,5}$ attracted the attention of many other kingdoms, which then entered the hypoxia battlefield, with "oncology" at the forefront. It quickly became clear that the crucial step in hypoxia-inducible gene expression is the oxygendependent destabilization of the HIF $\alpha$ subunit. But how oxygen interacted with HIF $\alpha$ remained a mystery well protected from the sorcerers of the invading kingdoms. Many mysterious molecular saboteurs were under suspicion, such as mitochondria, reactive oxygen species, redox state, general metabolism, and so on, but none of them could be arrested for HIF $\alpha$ destruction (reviewed by Wenger ${ }^{6}$ ).

This is when Sir Peter Ratcliffe and his men, including Patrick H Maxwell and Chris W Pugh, struck out for their first victory. By using a powerful weapon (antibodies against HIF-2 $\alpha$ ), still difficult to forge nowadays, they hunted down a tumor suppressor protein, known as "von Hippel-Lindau" (pVHL), guilty of oxygen- and iron-mediated HIF $\alpha$ demolition. ${ }^{7}$ Other strategies were blunt swords in this battle, because antibodies
Correspondence: Roland $\mathrm{H}$ Wenger Institute of Physiology, University of Zurich, Winterthurerstrasse 190, $\mathrm{CH}-8057$ Zurich, Switzerland

Tel +4l 446355065

Email roland.wenger@access.uzh.ch 
against HIF-1 $\alpha$ proved futile in studies using $p$ VHL-deficient renal cancer cell lines, simply because many of these cell lines initially contained supramaximal toxic HIF-1 $\alpha$ levels, which cancer selects against and instead selects for HIF-2 $\alpha$ expression. ${ }^{8}$ This seminal discovery of the E3 ligase pVHL, targeting HIF $\alpha$ for polyubiquitination and proteasomal degradation, finally provided the long-sought-for magic bullet that allowed the differentiation between hypoxic (nonmodified) and normoxic (modified) HIF $\alpha$, because pVHL stably interacts with HIF $\alpha$ only under conditions compatible with the presence of an enzymatic activity that is oxygen- and iron-dependent.

Once the front lines were set, the events were overturning. The alliance between the mighty forces led by Bill Kaelin on one side, and with Sir Peter Ratcliffe and his men on the other side, quickly resolved the covalent modification of HIF $\alpha$, which serves as recognition interface between HIF $\alpha$ and pVHL: oxygen derived from atmospheric air is used to hydroxylate two prolyl residues in the oxygen-dependent degradation domain of HIF $\alpha$ - a truly elegant and simple mechanism to combine oxygen sensing with signal transduction. ${ }^{9,10}$ What was remaining was the identification of the responsible enzyme(s), but the resistance to reveal this final secret was weak. Sir Peter Ratcliffe struck out for his second and final victory by employing a heretofore unknown fairy army hidden only a few steps away from his headquarters. With the help of the simple genetics of these almost invisible creatures (known to the informed world as Caenorhabditis elegans), a new family of enzymes could be identified which use oxygen and 2-oxoglutarate as cosubstrates to hydroxylate HIF $\alpha$ subunits and to produce succinate by oxidative decarboxylation of 2-oxoglutarate in an iron- and reducingagents-dependent process. ${ }^{11}$

During the following years, many scientists and companies were attracted by the shining lights of the treasures uncovered by Semenza, Ratcliffe, and Kaelin. Their findings fill libraries with more than 14,000 publications on HIF (and over 133,000 publications on hypoxia in general). Clinical trials are currently conducted, and it is likely that patients will soon profit from these amazing discoveries, a fact that was certainly also contributing to the decision to honor the Three "Musketairs" with the Lasker Prize.

The fandom is looking forward to the next chapters of the hypoxia saga to be written by our three heroes.

\section{Disclosure}

The authors report no conflicts of interest in this work.

\section{References}

1. Dumas A. The Three Musketeers. Abingdon-on-Thames: George Routledge and Sons, Ltd.; 1922.

2. Semenza GL, Wang GL. A nuclear factor induced by hypoxia via de novo protein synthesis binds to the human erythropoietin gene enhancer at a site required for transcriptional activation. Mol Cell Biol. 1992;12:5447-5454.

3. Wang GL, Jiang BH, Rue EA, Semenza GL. Hypoxia-inducible factor 1 is a basic-helix-loop-helix-PAS heterodimer regulated by cellular $\mathrm{O}_{2}$ tension. Proc Natl Acad Sci USA. 1995;92:5510-5514.

4. Wang GL, Semenza GL. General involvement of hypoxia-inducible factor 1 in transcriptional response to hypoxia. Proc Natl Acad Sci USA. 1993; 90:4304-4308.

5. Maxwell PH, Pugh CW, Ratcliffe PJ. Inducible operation of the erythropoietin 3' enhancer in multiple cell lines: evidence for a widespread oxygen-sensing mechanism. Proc Natl Acad Sci USA. 1993;90:2423-2427.

6. Wenger RH. Cellular adaptation to hypoxia: $\mathrm{O}_{2}$-sensing protein hydroxylases, hypoxia-inducible transcription factors, and $\mathrm{O}_{2}$-regulated gene expression. FASEB J. 2002;16:1151-1162.

7. Maxwell PH, Wiesener MS, Chang GW, et al. The tumour suppressor protein VHL targets hypoxia-inducible factors for oxygen-dependent proteolysis. Nature. 1999;399:271-275.

8. Shen C, Beroukhim R, Schumacher SE, et al. Genetic and functional studies implicate HIF $1 \alpha$ as a $14 q$ kidney cancer suppressor gene. Cancer Discov. 2011;1:222-235.

9. Ivan M, Kondo K, Yang H, et al. HIFa targeted for VHL-mediated destruction by proline hydroxylation: implications for $\mathrm{O}_{2}$ sensing. Science. 2001;292:464-468.

10. Jaakkola P, Mole DR, Tian YM, et al. Targeting of HIF-alpha to the von Hippel-Lindau ubiquitylation complex by $\mathrm{O}_{2}$-regulated prolyl hydroxylation. Science. 2001;292:468-472.

11. Epstein AC, Gleadle JM, McNeill LA, et al. C. elegans EGL-9 and mammalian homologs define a family of dioxygenases that regulate HIF by prolyl hydroxylation. Cell. 2001;107(1):43-54. Dove Medical Press encourages responsible, free and frank academic debate. The content of the Hypoxia 'Editorial' section does not necessarily represent the views of Dove Medical Press,
its officers, agents, employees, related entities or the Hypoxia editors. While all reasonable steps have been taken to confirm the content of each Editorial, Dove Medical Press accepts no
liability in respect of the content of any Editorial, nor is it responsible for the content and accuracy of any Editorial.

Hypoxia

Publish your work in this journal

Hypoxia is an international, peer-reviewed, open access journal that aims to improve understanding of the biological response to hypoxia. The journal will publish original research articles, reviews, methodological advances, clinical studies, and expert opinions that identify developments in the regulation of the physiological and pathological responses to

Submit your manuscript here: https://www.dovepress.com/hypoxia-journal

\section{Dovepress}

hypoxia and in the therapeutic targeting of hypoxia-responsive pathways. The manuscript management system is completely online and includes a very quick and fair peer-review system, which is all easy to use. Visit http://www.dovepress.com/testimonials.php to read real quotes from published authors. 